\title{
The general movements assessment in term and late-preterm infants diagnosed with neonatal encephalopathy, as a predictive tool of cerebral palsy by 2 years of age: a scoping review protocol
}

Judy Seesahai ${ }^{1,2}$, Maureen Luther ${ }^{1,2}$, Carmen Cindy Rhoden ${ }^{1,2}$, Paige Terrien Church ${ }^{1,2}$, Elizabeth Asztalos ${ }^{1,2}$ and Rudaina Banihani ${ }^{1,2^{*}}$

\begin{abstract}
Background: Prediction of long-term neurodevelopmental outcomes remains an elusive goal for neonatology. Clinical and socioeconomic markers have not proven to be adequately reliable. The limitation in prognostication includes those term and late-preterm infants born with neonatal encephalopathy. The General Movements Assessment tool by Prechtl has demonstrated reliability for identifying infants at risk for neuromotor impairment. This tool is non-invasive and cost-effective. The purpose of this study is to identify the published literature on how this tool applies to the prediction of cerebral palsy in term and late-preterm infants diagnosed with neonatal encephalopathy and so detect the research gaps.

Methods: We will conduct a systematic scoping review for data on sensitivity, specificity, positive, and negative predictive value and describe the strengths and limitations of the results. This review will consider studies that included infants more than or equal to $34+0$ weeks gestational age, diagnosed with neonatal encephalopathy, with a General Movements Assessment done between birth to six months of life and an assessment for cerebral palsy by at least 2 years of age. Experimental and quasi-experimental study designs including randomized controlled trials, non-randomized controlled trials, before and after studies, interrupted time-series studies and systematic reviews will be considered. Case reports, case series, case control, and cross-sectional studies will be included. Text, opinion papers, and animal studies will not be considered for inclusion in this scoping review as this is a highly specific and medical topic. Studies in the English language only will be considered. Studies published from at least 1970 will be included as this is around the time when the General Movements Assessment was first introduced in neonatology as a potential predictor of neuromotor outcomes. We will search five databases (MEDLINE, Embase, PsychINFO, Scopus, and CINAHL). Two reviewers will conduct all screening and data extraction independently. The articles will be categorized according to key findings and a critical appraisal performed.

(Continued on next page)
\end{abstract}

\footnotetext{
* Correspondence: rudaina.banihani@sunnybrook.ca

${ }^{1}$ Sunnybrook Health Sciences Centre, Toronto, Canada

2University of Toronto, Toronto, Ontario, Canada
}

(C) The Author(s). 2020 Open Access This article is licensed under a Creative Commons Attribution 4.0 International License, which permits use, sharing, adaptation, distribution and reproduction in any medium or format, as long as you give appropriate credit to the original author(s) and the source, provide a link to the Creative Commons licence, and indicate if changes were made. The images or other third party material in this article are included in the article's Creative Commons licence, unless indicated otherwise in a credit line to the material. If material is not included in the article's Creative Commons licence and your intended use is not permitted by statutory regulation or exceeds the permitted use, you will need to obtain permission directly from the copyright holder. To view a copy of this licence, visit http://creativecommons.org/licenses/by/4.0/ The Creative Commons Public Domain Dedication waiver (http://creativecommons.org/publicdomain/zero/1.0/) applies to the data made available in this article, unless otherwise stated in a credit line to the data. 
(Continued from previous page)

Discussion: The results of this review will guide future research to improve early identification and timely intervention in infants with neonatal encephalopathy at risk of neuromotor impairment.

Systematic review registration: Title registration with Joanna Briggs Institute https://joannabriggs.org/ebp/ systematic_review_register.

Keywords: Neonatal encephalopathy, General movement assessment, Prechtl, Hypoxia-ischemia encephalopathy, Cerebral palsy, Infants/neonates, Term babies, Preterm babies, Motor development

\section{Background}

Prediction of long-term neurodevelopmental outcomes remains an elusive goal for neonatology. Clinical and socioeconomic outcome markers have not proven to be adequately reliable $[1,2]$. The limitation in prognostication includes those term and late-preterm infants born with neonatal encephalopathy (NE).

NE describes those infants born with an atypical neurological exam and is by definition heterogeneous in etiology [3]. The specific etiology may not be clear for months to years later but the presentation is characterized by central nervous system disruption [4] and is associated with an increased risk for long-term neurodevelopmental challenges including cerebral palsy $(\mathrm{CP})$. Infants presenting with NE are managed now with therapeutic hypothermia as the standard of care; this is presumptive management, and is time sensitive should the etiology be hypoxia/ischemia (hypoxic-ischemic encephalopathy (HIE)), in term and latepreterm infants $[4,5]$. Therapeutic hypothermia reduces the likelihood of challenging outcomes by containing any potential ongoing neurological injury. It does not, however, completely eradicate the possibility of long-term neurodevelopmental disability [6].

For parents of infants affected by NE, the desire for accurate prognostication is of tantamount importance [7]. This information can guide decisions around early intervention and, in severe cases, withdrawal of care for those infants with severe involvement. For those infants that survive NE and are at increased risk for $\mathrm{CP}$, recent international recommendations now call for early detection and intervention of $\mathrm{CP}$ in order to improve functional outcomes $[1,8,9]$. These recommendations are based on mounting evidence for better detection tools as well as the benefits of early intervention.

Historically, clinical and radiological predictors of neurological outcomes were used to classify the degree of NE. Severity scoring systems include the classical grading by Sarnat and Sarnat [10] in 1976, to the newer scores by Miller et al. [11] in 2004, with added parameters such as oral feeding difficulties and the presence of seizures. Radiologically, specific findings of diffusion restriction on magnetic resonance imaging (MRI) have been linked to later development of $\mathrm{CP}$ [4]. These predictors, however, were not sufficiently accurate $[1,2]$ and the high costs of imaging as well as shortages in access further restricts the utility. Neurological examinations have historically been limited in predictive value but recent emerging evidence with an observational tool, the General Movements Assessment (GMA) developed by Dr. Heinz Prechtl has demonstrated strong predictive value $[12,13]$.

The GMA is a non-invasive, cost-effective tool with demonstrated reliability for identifying infants at risk for neuromotor impairment [14]. General movements (GMs) are complex, highly variable, whole-body movements which emerge in the fetus and progress through an agespecific developmental trajectory, dissipating by the end of the first 4 to 5 months of life [13]. Developmental progression and variety, or lack thereof, are indicators of nervous system integrity and can reflect neurodevelopmental outcomes [15]. Cramped synchronized (CS) and absent fidgety movements are considered abnormal GMAs, demonstrating developmental stereotypy [13].

Several researchers have looked at the GMA from different aspects. A preliminary search of PROSPERO, MEDLINE, the Cochrane Database of Systematic Reviews, and the Joanna Briggs Institute (JBI) Database of Systematic Reviews and Implementation Reports was conducted to assess this research. There were two current systematic reviews on GMA, one in 2018 [16] and the other in 2017 [8]. In addition, eight older reviews were identified: seven systematic reviews [13, 17-22] and one literature review [23] done between 2001 and 2013. The search also revealed three pending reviews identified around the topic of the predictive value of GMA [24-26]. These pending reviews were all systematic reviews.

The key characteristics and main findings of the above reviews on GMA are presented in Table 1 in Appendix 1. In general, the latest systematic review, by Kwong et al. in 2018 [16], compared assessments of GMA and found that the Prechtl method had the best prediction of CP. In the 2017 systematic review by Novak et al. [9], their group reviewed the evidence for the best tools for early, accurate diagnosis and intervention in infants at risk for CP. They considered all gestational ages (GA) and all diagnoses for infants that were high-risk. They recommended a combined approach for early $\mathrm{CP}$ diagnosis including history, neuroimaging, standardized neurological, and standardized motor assessments, to 
facilitate timely diagnosis and intervention. The other systematic reviews and literature review were all more than 5 years ago with the latest in 2013 [13]. The findings of these older reviews are also summarized in Table 1 in Appendix 1. Similar to the latest two reviews, the older reviews either looked at preterms or all GA groups and diagnoses.

Of the three pending systematic reviews identified in PROSPERO, the oldest review protocol (Kwong et al.) [26] was registered in 2016 by similar authors of the 2018 review mentioned above. The next review protocol was registered in February 2018 by Raghuram et al. [24], and plans restrictions to preterms with all diagnoses, specifically examining automated movement recognition technology with the GMA. The third review protocol, registered in April 2018, by Angélica Valencia [25] is limited to preterm infants and is evaluating the type of method used for the recognition of the GMA, not the relationship of the GMA to neuromotor outcomes. None of these reviews specifically look at the population we identified for this scoping review, that is, term and latepreterm infants with NE. Thus, a gap exists in the literature to clearly identify the evidence for this specific population.

The objective of this review is therefore, to identify the scope of the research with regard to the GMA and its ability to predict $\mathrm{CP}$, in term and late-preterm infants with a diagnosis of NE, and to identify the gaps in the literature.

\section{Methods/design}

\section{Review question}

The primary research question for this review is: What is the published data on the predictive value of the GMA for the diagnosis of CP by 2 years of age in infants born at term or late-preterm presenting with NE?

The secondary research question is: What is the gap in the literature when the GMA is used to predict CP by 2 years of age in infants born at term or late-preterm presenting with NE?

\section{Study design}

A scoping method is chosen for this type of review as to fulfilling of the objective of the review it requires searching and assessing a wide range of research methodologies involving the use of the GMA in CP prediction. A scoping review will capture all types of relevant research on the topic in a systematic, transparent, rigorous, and reproducible manner. This scoping review will be conducted in accordance with the JBI methodology for scoping reviews [27]. The objectives, inclusion criteria, and methods for this scoping review are detailed in advance and documented in a proposal (included as Additional file 1). The title of our review was registered with JBI.
Inherent in the nature of the scoping review is the inclusiveness of a wide range of literature, and so we anticipate differences in the data quality. Critical appraisal and data synthesis therefore will be challenging in terms of conclusive evidence as opposed to in a systematic review. The scoping review methodology is however especially advantageous to our question as these types of reviews target areas that have not been comprehensively assessed before.

\section{Eligibility criteria}

The participant, concept, context (PCC) framework for scoping reviews will be used to define the review focus and can be found in Table 2 in Appendix 2.

\section{Participants}

This review will consider studies that include infants $\geq$ $34+0$ weeks GA diagnosed with NE with a GMA done between birth to 6 months of life and an assessment for $\mathrm{CP}$ by at least 2 years of age (Table 2 in Appendix 2).

Reviews with infants born with life threatening congenital abnormalities, congenital viral infections, an abnormal karyotype and metabolic disorders will be excluded. Those studies without a GMA or with any automated application of the GMA will also be excluded.

\section{Concept}

GMA as a predictor of CP by 2 years of age is the main concept. Studies that report on sensitivity, specificity, positive predictive value (PPV), and negative predictive value (NPV) will be considered for inclusion. Detailed definition of concepts can be found in Table 3 in Appendix 3.

\section{Context}

This review will consider studies that reported on infants with an existing diagnosis of NE managed in hospitals and diagnosed by the standard of care assessment of a neurological history and examination. Studies will be considered from all countries that have outcomes reported in the acute neonatal and in the follow-up period by 2 years of age. Studies in the English language only will be considered as there is no team member with adequate language skills to translate from any other language.

\section{Search strategy}

A range of electronic databases will be searched to include medicine, nursing, allied health professions, sociology, psychology, education, and social work. This scoping review will consider both experimental and quasi-experimental study designs including randomized controlled trials, non-randomized controlled trials, before and after studies and interrupted time-series studies. Case reports, case series, case control, and cross-sectional studies will be included. In addition, systematic reviews that 
meet the inclusion criteria will be considered. Text and opinion papers will not be considered for inclusion in this scoping review as this is a highly specific and medical topic. Animal studies will not be included. Studies published from at least 1970 will be included as this is around the time when the GMA was first introduced in neonatology as a potential predictor of neuromotor outcomes [12]. The reference lists of articles will be scanned and experts in the infant developmental field will be consulted to identify studies relevant to our topic.

The search strategy will be phased, firstly created in Ovid MEDLINE using a combination of index terms and keywords around general movements, Prechtl, brain disease, HIE, and perinatal asphyxia. An initial limited search of Ovid MEDLINE, Embase, and PsychINFO was undertaken to identify articles on the topic (see Additional file 2). There were no previous similar reviews. The text words contained in the titles and abstracts of relevant articles, and the index terms used to describe the articles from this limited search will then be used to develop a more refined full search strategy in the second phase, for MEDLINE, Embase, PsychINFO, Scopus, and CINAHL (Appendix 3). The search strategy, including all identified keywords and index terms, will be adapted for each included information source.

\section{Study selection}

EndNote X9 will be used for citation collation. Duplicates will be removed manually. Covidence will be used for screening by two independent reviewers (JS and $\mathrm{ML}$ ). Disagreements will be resolved through a third reviewer (RB). The results of the search will be reported in a Preferred Reporting Items for Systematic Reviews and Meta-analyses extension for scoping reviews (PRISMAScR) flow diagram [28].

\section{Data extraction, analysis, and synthesis}

Publications meeting the inclusion criteria will have a full text review to validate their eligibility. Each article will be assessed independently by two authors (JS and $\mathrm{RB})$. Extraction will be done after full text screening using a data extraction tool developed by the reviewers. Excluded studies closely meeting the inclusion criteria will be included in a separate table as they may contain many elements of our inclusion criteria but not present separately the specific criteria of our interest. Further investigation of their data may provide significant results. Authors will be contacted to access further information and reassess eligibility of these studies. Excluded studies will be documented with reasons for their exclusion.

The data extracted from the identified studies will include specific details about the population, concept, and context. Two tables will be generated with the first table having information on the key characteristics of each study, including author, year of publication, geographical setting, type of study, demographics of the participants, period over which the study was conducted, the method of identification of neonates at high-risk, if therapeutic hypothermia was instituted as management for NE, type of spontaneous movement assessment used, age at which participants were assessed, the age at which $\mathrm{CP}$ was diagnosed, and the methods used for neurological examination in the studies. The second table will have information on the key findings, the predictive indices used for the GMA in relation to CP (sensitivity, specificity, PPV, and NPV), limitations of the studies, and where relevant, reasons for exclusion in the studies that met most but not all of the inclusion criteria. These lists will be iterative. As the process evolves, the data extraction form may require modification to ensure all relevant information is included. Additionally, even though this was a scoping review and does not require a critical appraisal, the critical appraisal tool for JBI [29] will help to identify differences and similarities between the included studies. The answers to the JBI critical appraisal tool will be detailed in a table.

\section{Discussion}

The extracted data will be presented in diagrammatic or tabular form in a manner that aligns with the objective of this scoping review. A narrative summary will accompany the tabulated and/or charted results and will describe how the results relate to the reviews objective and question. The critical appraisal result will also be tabulated and this will be used to further identify the strengths and limitations of the studies as well as the key findings in relationship to the objective of this scoping review. The strengths and limitations of our scoping review method on the credibility of the results will be detailed. The discussion and conclusions will reflect on the implications for future research and patient management.

\section{Protocol amendments}

Important amendments to the protocol will be reported with the results of the review.

\section{What this study will add}

This study will examine the scope of the literature with respect to the use of the GMA in NE for the prediction of CP. Assessment of the extent of the knowledge on this topic seems to have not previously been done. By inclusion of a critical appraisal of the available relevant literature, it will facilitate an appreciation of the quality of the existing knowledge in this area. It will therefore identify gaps in the research especially in the setting of NE management with therapeutic hypothermia. 


\section{Appendix 1}

Table 1 Summary of reviews (published and pending) on the general movements assessment and its predictive value for neuromotor outcomes

\begin{tabular}{|c|c|c|c|c|c|c|c|}
\hline Article & $\begin{array}{c}\text { Date of } \\
\text { publication }\end{array}$ & Country & $\begin{array}{c}\text { Type of studies } \\
\text { included }\end{array}$ & $\begin{array}{l}\text { Population (general } \\
\text { characteristics) }\end{array}$ & GM assessment & Key findings & Predictive value \\
\hline $\begin{array}{l}\text { Published syst } \\
\text { Kwong } \\
\text { et al. }{ }^{16}\end{array}$ & $\begin{array}{l}\text { matic reviews } \\
2018\end{array}$ & Australia & Cohort studies & $\begin{array}{l}\text { All GA with a GM. GM } \\
\text { assessment done } \\
\text { between } 37 \text { wks to }<5 \\
\text { months of age }\end{array}$ & $\begin{array}{l}\text { Prechtl, Hadders- } \\
\text { Algra and } \\
\text { Hammersmith }\end{array}$ & $\begin{array}{l}47 \text { studies } \\
\text { Fidgety movements using Prechtl } \\
\text { method had the best prediction of } \\
\text { cerebral palsy }\end{array}$ & $\begin{array}{l}\text { Sensitivity 97\% (95\% Cl 93-99) } \\
\text { Specificity } 89 \%(95 \% \mathrm{Cl} 83-97) \text { but } \\
\text { had false positive results so cannot } \\
\text { be used in isolation }\end{array}$ \\
\hline $\begin{array}{l}\text { Novak } \\
\text { et al. }\end{array}$ & 2017 & Australia & $\begin{array}{l}\text { Systematic } \\
\text { reviews and } \\
\text { evidence-based } \\
\text { clinical } \\
\text { guidelines }\end{array}$ & $\begin{array}{l}\text { All GA } \\
\text { All high-risk or low birth } \\
\text { weight }\end{array}$ & $\begin{array}{l}\text { Prechtl and } \\
\text { Hammersmith }\end{array}$ & $\begin{array}{l}6 \text { systematic reviews and } 2 \\
\text { evidence-based clinical guidelines. } \\
\text { For infants with newborn- } \\
\text { detectable risks before } 5 \text { months' } \\
\text { corrected age, the GMs assessment } \\
\text { plus neonatal MRI is }>95 \% \\
\text { accurate. } \\
\text { For infants with infant } \\
\text { detectable risks after } 5 \text { months' } \\
\text { corrected age, the HINE plus } \\
\text { neonatal MRI is more than } 90 \% \\
\text { accurate and is therefore } \\
\text { recommended }\end{array}$ & $\begin{array}{l}\text { Sensitivity 98\% for Prechtl GM } \\
\text { assessment }\end{array}$ \\
\hline $\begin{array}{l}\text { Bosquanet } \\
\text { et al. }{ }^{13}\end{array}$ & 2013 & Australia & $\begin{array}{l}\text { English studies } \\
\text { only of } \\
\text { randomized } \\
\text { control trials } \\
\text { and cohort } \\
\text { trials both } \\
\text { prospective and } \\
\text { retrospective }\end{array}$ & $\begin{array}{l}23-41 \text { veeeks } G A \\
\text { All GA in high-risk } \\
\text { populations } \\
1358 \text { participants }\end{array}$ & $\begin{array}{l}\text { Any GM assessment } \\
\text { type }\end{array}$ & $\begin{array}{l}19 \text { studies } \\
\text { GM assessment had the best } \\
\text { evidence and strength for prediction } \\
\text { of cerebral palsy in }<5 \text {-year olds } \\
\text { chmpared to neurological } \\
\text { examination, MRI and cranial } \\
\text { ultrasound. } 1 \text { of the } 19 \text { studies was } \\
\text { term babies, rest preterm }\end{array}$ & 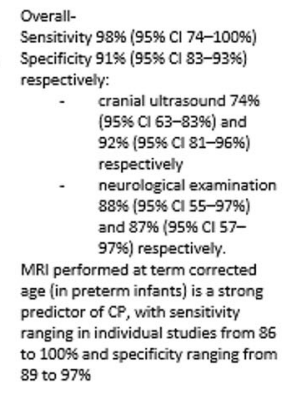 \\
\hline $\begin{array}{l}\text { Noble } \\
\text { et al. }{ }^{27}\end{array}$ & 2012 & Australia & $\begin{array}{l}\text { Not stated, } \\
\text { possibly all } \\
\text { types }\end{array}$ & All preterm infants & $\begin{array}{l}\text { Any GM assessment } \\
\text { tool }\end{array}$ & $\begin{array}{l}\text { Reviewed clinimetric properties of } \\
\text { longitudinal neonatal } \\
\text { neurobehavioural and neuromotor } \\
\text { assessments showed GMs was best } \\
\text { for prediction of future outcome } \\
\text { while the TIMP has best evaluative } \\
\text { validity }\end{array}$ & $\begin{array}{l}\text { Predictive validity for } \mathrm{CP} \text { at } 12 \text { to } 24 \\
\text { months was high for } \mathrm{GMs} \text { : } \\
-\quad \text { Sensitivity } 100 \% \\
\text { Interrater reliability: } \\
\text { - TIMP intraclass } \\
\text { correlation=0.95 (strong) } \\
\text { - } \mathrm{GMs} \text { ( } \mathrm{K}=0.8 \text { ) } \\
\text { NAPI } \mathrm{r}=0.67-0.97 \\
\text { (moderate) }\end{array}$ \\
\hline $\mathrm{zuk}^{18}$ & 2011 & Israel & $\begin{array}{l}\text { Longitudinal } \\
\text { follow up } \\
\text { studies mainly }\end{array}$ & $\begin{array}{l}\text { All GA } \\
\text { Heterogenous } \\
\text { diagnoses }\end{array}$ & Prechtl & $\begin{array}{l}37 \text { studies } \\
35 \text { longitudinal follow-ups, } 2 \text { n.s. }\end{array}$ & $\begin{array}{l}\text { CS GMs that are consistent are } \\
\text { highly predictive for CP. } \\
\text { FMS were a sensitive predictor of } \\
\text { neurodevelopmental outcome in } \\
\text { different populations of infants. } \\
\text { Sensitivity > 90\% for these FMs and } \\
\text { neurodevelopmental outcomes. } \\
\text { Sensitivity > 90\% for a normal } \\
\text { outcome when the GMs were } \\
\text { normal }\end{array}$ \\
\hline $\begin{array}{l}\text { Darsaklis et } \\
\text { al. }^{10}\end{array}$ & 2011 & Canada & $\begin{array}{l}\text { Longitudinal } \\
\text { cohort studies } \\
\text { in English and } \\
\text { French }\end{array}$ & All GA & $\begin{array}{l}\text { Pretchl's method } \\
\text { only }\end{array}$ & 39 studies & $\begin{array}{l}\text { Conflicting evidence on whether the } \\
\text { quality of fidgety or writhing } \\
\text { movements is more accurate in } \\
\text { predicting neurodevelopmental } \\
\text { outcomes at } 4 \text { points in follow up- } \\
12 \text { to } 23 \text { months, } 2 \text { to } 3 \text { years, } 4 \text { to } \\
11 \text { years and } 12 \text { to } 18 \text { years }\end{array}$ \\
\hline $\begin{array}{l}\text { Burger et } \\
\text { at. }^{20}\end{array}$ & 2009 & $\begin{array}{l}\text { United } \\
\text { Kingdom }\end{array}$ & $\begin{array}{l}\text { Descriptive } \\
\text { research } \\
\text { studies vith } \\
\text { predictive value } \\
\text { at 12-or } 24 \text { - } \\
\text { months } \\
\text { corrected age }\end{array}$ & $\begin{array}{l}\text { All GA } \\
1926 \text { participants }\end{array}$ & $\begin{array}{l}\text { Pretchl's method } \\
\text { only }\end{array}$ & $\begin{array}{l}17 \text { studies } \\
\text { Qualitative assessment of GM } \\
\text { especially in the fidgety stage may } \\
\text { be prognostic of } \\
\text { neurodevelopmental impairment } \\
\text { but the validity of the included } \\
\text { studies was uncertain and o GM } \\
\text { assessments should be used in } \\
\text { combination with neuro-imaging or } \\
\text { standardized neurological } \\
\text { evaluations }\end{array}$ & $\begin{array}{l}\text { Average score of the studies } \\
8.82 \text { (73.5\%) from a total } \\
\text { of } 12 \text { (SD 0.73). } \\
15 \text { of } 17 \text { studies showed } \\
\text { high relationship } \\
\text { (sensitivity } 92 \% ; \\
\text { specificity } 82 \% ; p<0.01 \text { ) } \\
\text { in figety movements' } \\
\text { period }\end{array}$ \\
\hline $\begin{array}{l}\text { Spittle et } \\
\text { al.2. }\end{array}$ & 2008 & Australia & $\begin{array}{l}\text { Only studies in } \\
\text { English }\end{array}$ & $\begin{array}{l}\text { Clinimetric tools to } \\
\text { predict outcomes in } \\
\text { preterm infants (less } \\
\text { than } 37 \text { week's GA) } \\
\text { during their first year of } \\
\text { life }\end{array}$ & Any GM assessment & $\begin{array}{l}\text { The AIMS, TIMP, and GMs } \\
\text { demonstrated the highest levels of } \\
\text { overall reliability. Selection of motor } \\
\text { assessment tools during the first } \\
\text { year of life for infants born preterm } \\
\text { will depend on the intended } \\
\text { purpose of their use for } \\
\text { discrimination, prediction, and/or } \\
\text { evaluation }\end{array}$ & $\begin{array}{l}\text { Overall reliability: } \\
18 \text { different assessment } \\
\text { types } \\
\text { the AIMS, TIMP, and } \\
\text { GMs had the highest } \\
\text { levels of (interrater and } \\
\text { intrarater intraclass } \\
\text { correlation coefficient or } \\
\kappa>0.85 \text { ) }\end{array}$ \\
\hline $\begin{array}{l}\text { Hadders- } \\
\text { Algra et al. }{ }^{22}\end{array}$ & 2001 & $\begin{array}{l}\text { The } \\
\text { Netherlands }\end{array}$ & $\begin{array}{l}\text { Research } \\
\text { reports }\end{array}$ & Preterm and term & Any GM assessment & $\begin{array}{l}\text { Absence of complexity and variety } \\
\text { of } G M \text { at } 2-4 \text { months post-term } \\
\text { have a high risk for } C P\end{array}$ & Nil \\
\hline
\end{tabular}


Table 1 (Continued)

\begin{tabular}{|c|c|c|c|c|c|c|c|}
\hline Article & $\begin{array}{c}\text { Date of } \\
\text { publication }\end{array}$ & Country & $\begin{array}{c}\text { Type of studies } \\
\text { included }\end{array}$ & $\begin{array}{l}\text { Population (general } \\
\text { characteristics) }\end{array}$ & GM assessment & Key findings & Predictive value \\
\hline \multicolumn{8}{|c|}{ Published literature review: } \\
\hline $\begin{array}{l}\text { Santos et } \\
\text { al. }\end{array}$ & 2008 & Brazil & $\begin{array}{l}\text { Any study with } \\
\text { evaluation tests } \\
\text { to detect } \\
\text { developmental } \\
\text { disorders }\end{array}$ & $\begin{array}{l}\text { All GA } \\
\text { All high-risk diagnoses }\end{array}$ & Prechtl & 174 studies & $\begin{array}{cl}\text { GM reliability rate: } \\
-\quad \text { Sensitivity: } 100 \% \\
-\quad \text { Specificity: } 96 \%\end{array}$ \\
\hline \multicolumn{8}{|c|}{ Proposed reviews from PROSPERO (published protocols): } \\
\hline $\begin{array}{l}\text { Raghuram } \\
\text { et al. }{ }^{24}\end{array}$ & Feb 2018 & Canada & $\begin{array}{l}\text { Any study, } \\
\text { including } \\
\text { randomized, } \\
\text { quasi- } \\
\text { randomized, } \\
\text { non- } \\
\text { randomized } \\
\text { clinical trials, } \\
\text { retrospective or } \\
\text { prospective } \\
\text { observational } \\
\text { trials, pilot } \\
\text { studies, and } \\
\text { feasibility } \\
\text { studies }\end{array}$ & $\begin{array}{l}\text { Preterm and term } \\
\text { neonates with all high- } \\
\text { risk diagnoses and the } \\
\text { ability of an automated } \\
\text { movement recognition } \\
\text { technology for } \\
\text { GM Assessment to } \\
\text { predict motor } \\
\text { impairment }\end{array}$ & Details not provided & Pending review completion & \\
\hline Valencia ${ }^{25}$ & Apr 2018 & France & $\begin{array}{l}\text { Any study in } \\
\text { English, French } \\
\text { or Spanish }\end{array}$ & $\begin{array}{l}\text { Preterm before the } \\
\text { term age with any } \\
\text { diagnostic. } \\
\text { Evaluating the evidence } \\
\text { on discriminative and } \\
\text { predictive validity of } \\
\text { the GM assessment } \\
\text { performed on preterm } \\
\text { infants on } \\
\text { neurodevelopmental } \\
\text { outcome }\end{array}$ & Details not provided & Pending review completion & \\
\hline $\begin{array}{l}\text { Kwong et } \\
\text { al.2. }\end{array}$ & July 2016 & Australia & $\begin{array}{l}\text { Cohort } \\
\text { predictive } \\
\text { studies, } \\
\text { prospective or } \\
\text { retrospective }\end{array}$ & $\begin{array}{l}\text { > } 37 \text { weeks GA } \\
\text { Infants assessed } \\
\text { between more than or } \\
\text { equal to } 37 \text { weeks } \\
\text { gestational age - less } \\
\text { than } 5 \text { months } \\
\text { corrected } \\
\text { age and reassessed at }\end{array}$ & Details not provided & Pending review completion & \\
\hline
\end{tabular}

Note. AIMS=The Alberta infant motor scale, $\mathrm{Cl}=$ confidence interval, $\mathrm{CP}=$ cerebral palsy, $\mathrm{CS}=\mathrm{cramped}$ synchronized, $\mathrm{GM}=\mathrm{general}$ movement, $\mathrm{HINE}=\mathrm{Hammersmith}$ Infant Neurological Examination, NAPI=Neurobehavioural Assessment of the Preterm Infant, n.s. = not stated, TIMP=Test of infant motor performance, wks = weeks

\section{Appendix 2}

Table 2 Inclusion and exclusion criteria for the prediction of CP by the GMA in late-preterm and term infants with NE

\begin{tabular}{lll}
\hline & Inclusion criteria & Exclusion criteria \\
\hline Participants & Infants $\geq 34+0$ weeks GA & Infants born with: \\
& Diagnosis of NE & - Life threatening congenital \\
& GMA done between birth up to 6 months of life & abnormalities \\
& Assessment for CP by at least 2 years of age & - Congenital viral infections \\
& & - An abnormal karyotype and \\
Concept & GMA as a predictor of CP by 2 years of age is the main concept. & - Metabolic disorders \\
Context & Studies that reported on the following: & \\
& -Infants with NE managed in hospitals and diagnosed by the standard of care (neurological history \\
& and examination) & \\
& -Studies from all countries that have outcomes reported in the acute neonatal and in the follow-up \\
& period by 2 years of age \\
& -Studies in the English language only
\end{tabular}




\section{Appendix 3}

Table 3 Definitions of concepts

\begin{tabular}{|c|c|}
\hline Concepts & Definition \\
\hline Neonatal encephalopathy & $\begin{array}{l}\text { A clinically defined syndrome of disturbed neurologic function in the earliest days of life in an infant born at or beyond } \\
35 \text { weeks of gestation, manifested by a subnormal level of consciousness or seizures, and often accompanied by difficulty } \\
\text { with initiating and maintaining respiration and depression of tone and reflexes [3] }\end{array}$ \\
\hline Late-preterm & Neonates $\geq 34+0$ to $36+6$ weeks GA [30] \\
\hline Term & Neonates $37+0$ to $42+6$ weeks GA [30] \\
\hline Cerebral palsy & $\begin{array}{l}\text { A group of permanent disorders of the development of movement and posture causing activity limitations that are } \\
\text { attributed to non-progressive disturbances that occurred in the developing fetal or infant brain [31] }\end{array}$ \\
\hline General movements & $\begin{array}{l}\text { These are spontaneous movements present from early fetal life until about } 6 \text { months of life. GMs are variable, complex } \\
\text { movements that occur frequently, lasting long enough to be observed. The whole body is involved in a variable } \\
\text { sequence of limbs, neck, and trunk movements. Waxing and waning in intensity, force, and speed, they have a gradual } \\
\text { beginning and end. They involve rotations along the limb axis. Slight changes in direction are responsible for their fluid } \\
\text { elegance. Impairment of the nervous system causes the loss of GMs complexity and variability resulting in monotonous } \\
\text { and poor-quality movements. } \\
\text { Specific abnormal GM patterns have been identified that reliably predict later cerebral palsy: } \\
\text { (1) Cramped-synchronized GMs - a persistence of rigid movements that lack the normal fluidity. Contractions and relaxa- } \\
\text { tions occur almost concurrently in limb and trunk muscles. } \\
\text { (2) The absence of fidgety GMs-fidgety movements are small movements of moderate speed with variable acceleration } \\
\text { of neck, trunk, and limbs in all directions. Normally, they are the predominant movement pattern in an awake infant at } 3 \\
\text { to } 5 \text { months [32]. }\end{array}$ \\
\hline $\begin{array}{l}\text { General movements } \\
\text { assessment }\end{array}$ & $\begin{array}{l}\text { A comfortably dressed infant, preferably with bare arms and legs, is videoed in supine position. The duration of the video } \\
\text { recording will depend on the age of the infant with premature infants requiring up to } 30 \text { to } 60 \text { minutes. Term age and } \\
\text { older require } 5 \text { to } 10 \text { min of optimal recording. This recording does not require the observer's presence. The trained } \\
\text { observer reviews the recording later. The assessment is based on global visual Gestalt perception without acoustic signal } \\
\text { to reduce distraction. Two to three recordings of the preterm, one recording at term or early post-term age or both, and } \\
\text { at least one recording between 9- and } 15 \text {-week post-term forms the basis of a developmental trajectory. An individual } \\
\text { developmental trajectory indicates the consistency or inconsistency of normal or abnormal findings [32]. }\end{array}$ \\
\hline Sensitivity & The proportion of true positives that are correctly identified in a sample, or the true positive rate [33]. \\
\hline Specificity & The proportion of true negatives that are correctly identified in a sample, or the true negative rate [33]. \\
\hline Positive predictive value & The proportion of patients with positive test results who are correctly diagnosed [34]. \\
\hline Negative predictive value & The proportion of patients with negative test results who are correctly diagnosed [34]. \\
\hline
\end{tabular}

Note. GA gestational age, GMs general movements

\section{Supplementary information}

Supplementary information accompanies this paper at https://doi.org/10. 1186/s13643-020-01358-x.

Additional file 1. The General Movements Assessment in Term and Late-preterm newborns diagnosed with Neonatal Encephalopathy, as a predictive tool of Cerebral Palsy at two years of age - A Scoping Review

Additional file 2. Ovid MEDLINE search. Search conducted on Ovid MEDLINE(R), Ovid MEDLINE(R) Daily and Epub Ahead of Print, In-Process \& Other Non-Indexed Citations 1946 to Present

\section{Abbreviations \\ CP: Cerebral palsy; CS: Cramped synchronized; GMs: General movements; GA: Gestational age; GMA: General Movements Assessment; HIE: Hypoxic- ischemic encephalopathy; JBI: Joanna Briggs Institute; MRI: Magnetic resonance imaging; NE: Neonatal encephalopathy; NPV: Negative predictive value; PCC: Participant, concept, context; PPV: Positive predictive value; PRISMA-SCR: Preferred Reporting Items for Systematic Reviews and Meta- analyses extension for scoping review}

\section{Acknowledgements}

This review will contribute to a Master in Healthcare Quality degree for JS. The authors would also like to acknowledge the librarians that assisted with this research project, namely, from the Sunnybrook R. Ian MacDonald Library, Henry Lam and Reena Besa, as well as the librarians Paola Durando and Sandra McKeown of the Bracken Health Sciences Library, Queen's University.

\section{Authors' contributions}

First author: Judy Seesahai. Contributions: Substantial contributions to research design, acquisition, analysis and interpretation of data as well as drafting the paper. Second author: Maureen Luther. Contributions: Contribution to acquisition, analysis, and interpretation of data as well as involved in revisions to the paper. Paige Terrien Church. Contributions: Substantial contributions to research design, analysis, and interpretation of data as well as drafting the paper. Carmen Cindy Rhoden. Contributions: Initial data search and drafting of paper. Elizabeth Azstalos. Contributions: Substantial contributions to research design, acquisition, analysis, and interpretation of data as well as drafting the paper. Supervisor: Thomas Rotter. Contributions: Substantial contributions to research design and reviewing of the paper. Principal Investigator: Rudaina Banihani. Contributions: Substantial contributions to research design, acquisition, analysis, and interpretation of data as well as drafting the paper. The author(s) read and approved the final manuscript.

\section{Funding}

There is no funding required for this review.

\section{Availability of data and materials}

Data sharing is not applicable to this article as no datasets were generated or analyzed during the current study. Materials during the current study are available from the corresponding author on reasonable request.

\section{Ethics approval and consent to participate}

Ethical approval will not be required as this is a scoping review of the literature and will not contain information directly identifying patients or content requiring patient consent. 


\section{Consent for publication}

Not applicable

\section{Competing interests}

The authors declare that they have no competing interests.

Received: 13 January 2020 Accepted: 13 April 2020

Published online: 04 July 2020

\section{References}

1. Finer NN, Robertson CM, Richards RT, Pinnell LE, Peters KL. Hypoxic-ischemic encephalopathy in term neonates: perinatal factors and outcome. J Pediatr. 1981;98(1):112-7. https://doi.org/10.1016/s0022-3476(81)80555-0.

2. Campbell EE, Gilliland J, Dworatzek PDN, De Vrijer B, Penava D, Seabrook JA. Socioeconomic status and adverse birth outcomes: A population-based Canadian sample. Journal of Biosocial Science Cambridge University Press. 2018;50(1):102-13.

3. Executive Summary: Neonatal Encephalopathy and Neurologic Outcome, Second Edition. Obstetrics \& Gynecology, (2014) 123(4), 896-901. doi: 10 1097/01.AOG.0000445580.65983.d2.

4. Glass HC. Hypoxic-ischemic encephalopathy and other neonatal encephalopathies. [Review]. Continuum (Minneap Minn). 2018 Feb;57-71.

5. American Academy of Pediatrics, Committee on Fetus and Newborn. Hypothermia and neonatal encephalopathy. Pediatrics. 2014;133(6):1146-50.

6. Staub K, Baardsnes J, Hébert N, Hébert M, Newell S, Pearce R. Our child is not just a gestational age. A first-hand account of what parents want and need to know before premature birth. Acta Paediatr. 2014;103(10):1035-8.

7. Banihani R TCP. Neonatal encephalopathy. In: Needelman H JB, editor. Follow-Up for NICU Graduates. 2018. p. 155-78.

8. Shepherd E, Salam RA, Middleton P, Han S, Makrides M, Mclntyre S, et al. Neonatal interventions for preventing cerebral palsy: an overview of Cochrane Systematic Reviews. Cochrane Database of Systematic Reviews 2018, Issue 6. Art. No.: CD012409. DOI: 10.1002/14651858.CD012409.pub2.

9. Novak I, Morgan C, Adde L, et al. Early, accurate diagnosis and early intervention in cerebral palsy: advances in diagnosis and treatment. JAMA Pediatr. 2017;171(9):897-907. https://doi.org/10.1001/ jamapediatrics.2017.1689.

10. Sarnat H, Sarnat M. Neonatal encephalopathy following fetal distress. Arch Neurol. 1976:33:695-705

11. Miller SP, Latal B, Clark H, Barnwell A, Glidden D, Barkovich AJ, et al. Clinica signs predict 30-month neurodevelopmental outcome after neonatal encephalopathy. Am J Obstet Gynecol. 2004;190(1):93-9. https://doi.org/10. 1016/S0002-9378(03)00908-6.

12. Einspieler C, Prechtl HFR, Bos AF, Ferrari F, Cioni G. In: Hart HM, Pountney M, Pearsall S (Editors). Developmental Medicine No. 167. Prechtl's method on the qualitative assessment of general movements in preterm, term and young infants. 1st ed. Mac Keith Press c 2004. p ix - xi.

13. Bosanquet M, Copeland L, Ware R, Boyd R. A systematic review of tests to predict cerebral palsy in young children. Dev Med Child Neurol. 2013;55: 418-26.

14. Heineman KR, Hadders-Algra M. Evaluation of neuromotor function in infancy-A systematic review of available methods. J Dev Behav Pediatr. 2008: Aug 29(4):315-23. doi: 10.1097/DBP.0b013e318182a4ea.

15. Hadders-Algra M. General Movements: A Window for early identification of children at high risk for developmental disorders. J Pediatr. 2004;145(2 Supplement):S12-8.

16. Kwong AKL, Fitzgerald TL, Doyle LW, Cheong JL, Spittle AJ. Predictive validity of spontaneous early infant movement for later cerebral palsy: a systematic review. Dev Med Child Neurol. 2018:60(5):480-9.

17. Noble Y, Boyd R. Neonatal assessments for the preterm infant up to 4 months corrected age: a systematic review. Dev Med Child Neurol. 2012;54:129-39.

18. Zuk L. Fetal and infant spontaneous general movements as predictors of developmental disabilities. Dev Disabil Res Rev 2011;17:93-101. Available from: https://proxy.queensu.ca/login?url=http://ovidsp.ovid.com?T=JS\&CSC= $Y \& N E W S=N \& P A G E=$ fulltext\&D=med7\&AN=23362029, https://onlinelibrary. wiley.com/doi/abs/10.1002/ddrr.1104, https://dx.doi.org/10.1002/ddrr.1104.

19. Darsaklis V, Snider LM, Majnemer A, Mazer B. Predictive validity of Prechtl's method on the qualitative assessment of general movements: a systematic review of the evidence. Dev Med Child Neurol. 2011;53(10):896-906.

20. Burger M, Louw QA. The predictive validity of general movements-a systematic review. Eur J Paediatr Neurol. 2009;13(5):408-20.
21. Spittle AJ, Doyle LW, Boyd RN. A systematic review of the clinimetric properties of neuromotor assessments for preterm infants during the first year of life. Dev Med Child Neurol. 2008;50(4):254-66.

22. Hadders-Algra M. Evaluation of motor function in young infants by means of the assessment of general movements: a review. Pediatr Phys Ther. 2001; 13(1):27-36.

23. Santos RS, Araújo APQC, Porto MAS. Early diagnosis of abnormal development of preterm newborns: assessment instruments. J. Pediatr. (Rio J.) [Internet]. 2008 Aug [cited 2019 Aug 07];84(4):289-299. Available from: http://www.scielo.br.proxy.queensu.ca/scielo.php?script=sci_arttext\&pid= S0021-75572008000400003\&lng=en, http://dx.doi.org.proxy.queensu.ca/10.15 90/S0021-75572008000400003.

24. Raghuram K, Orlandi S, Church P, Chau T, Uleryk E, Pechlivanoglou P, et al. Can an automated general movements assessment be used to predict motor impairment in high-risk infants? A systematic review and metaanalysis of diagnostic accuracy. PROSPERO International prospective register of systematic reviews. 2018 Apr 16; Available from: http://www.crd.york.ac. uk/PROSPERO/display_record.php?ID=CRD42018087892.

25. Valencia A. Discriminative and predictive validity of the general movements assessment: a systematic review. PROSPERO International prospective register of systematic reviews. 2018 14;Available from: http://www.crd.york. ac.uk/PROSPERO/display record.php?ID=CRD42018088724.

26. Kwong AKL, Fitzgerald TL, Spittle AJ, Cheong JL, Doyle LW, Einspieler C. A systematic review of the predictive validity of observational early infant motor assessments for subsequent cerebral palsy. PROSPERO International prospective register of systematic reviews. 2016; Available from: http://www. crd.york.ac.uk/PROSPERO/display_record.php?ID=CRD42016042551.

27. The Joanna Briggs Institute. The System for the Unified Management, Assessment and Review of Information (SUMARI) [Internet]. 2017 [cited 2019]. Available from: https://www.jbisumari.org/.

28. Moher D, Liberati A, Tetzlaff J, Altman DG. Preferred Reporting Items for Systematic Reviews and Meta-Analyses: The PRISMA Statement. [Internet]. 2009 [cited 2019]. Available from: http://prisma-statement.org/ PRISMAStatement/FlowDiagram.aspx.

29. Moola S, Munn Z, Tufanaru C, Aromataris E, Sears K, Sfetcu R, Currie M, Qureshi R, Mattis P, Lisy K, Mu P-F. Chapter 7: Systematic reviews of etiology and risk. In: Aromataris E, Munn Z (Editors). Joanna Briggs Institute Reviewer's Manual. The Joanna Briggs Institute, 2017. Available from https:// reviewersmanual.joannabriggs.org/.

30. World Health Organization. ICD-10 International Statistical Classification of Diseases and Related Health Problems: 10th Revision, Volume 2 Instruction Manual. www.who.int/classifications/icd/ICD-10_2nd_ed_volume2.pdf (Accessed on September 7, 2010).

31. Rosenbaum $P$, Paneth $N$, Leviton $A$, et al. A report: the definition and Classification of cerebral palsy April 2006. Dev Med Child Neurol Suppl. 2007;109:8-14.

32. Einspieler C, Prechtl HFR. Prechtl's assessment of general movements: a diagnostic tool for the functional assessment of the young nervous system. Ment.Retard.Dev.Disabil.Res.Rev. 2005;11(1):61-6.

33. Altman DG, Bland JM. Diagnostic tests. 1: Sensitivity and specificity. BMJ (Clinical research ed.), 308(6943), 1552. 1994. https://doi.org/10.1136/bmj. 308.6943.1552

34. Altman DG, Bland JM. Diagnostic tests 2: Predictive values. BMJ (Clinical research ed). 1994;309(6947):102. https://doi.org/10.1136/bmj.309.6947.102.

\section{Publisher's Note}

Springer Nature remains neutral with regard to jurisdictional claims in published maps and institutional affiliations. 